\title{
Irradiance Level and Fertilizer Rate Affect Acclimatization of Chamaedorea elegans Mart.
}

\author{
Trinidad Reyes, Terril A. Nell, James E. Barrett, and \\ Charles A. Conover \\ Department of Environmental Horticulture, University of Florida, Gainesville, \\ FL 32611-0670
}

Additional index words. plant quality, longevity

\begin{abstract}
The effect of irradiance and fertilizer level on the acclimatization of Chamaedorea elegans Mart. was studied. Chamaedorea elegans was grown for 4 months in 1.6-liter pots under 162,306 , or $564 \mu \mathrm{mol} \cdot \mathrm{m}^{-2} \cdot \mathrm{s}^{-1}$ and fertilized weekly with $20 \mathrm{~N}-4.7 \mathrm{P}-16.6 \mathrm{~K}$ soluble fertilizer at 220,440 , or $880 \mathrm{mg} /$ pot. At the end of the production period, plants were moved to interior rooms and maintained for 2 months at $20 \mu \mathrm{mol} \cdot \mathrm{m}^{-2} \cdot \mathrm{s}^{-1}$ for $12 \mathrm{~h}$ daily at $21 \pm 1 \mathrm{C}$ and a relative humidity of $50 \% \pm 5 \%$. At the end of the production phase, the light compensation point (LCP) and the concentration of nonstructural carbohydrates were lower, and chlorophyll concentration was higher the lower the irradiance level. Increasing fertilizer concentration decreased the number of fronds, LCP, and nonstructural carbohydrates. After 2 months in the interior environment, LCP and number of fronds of $C$. elegans did not differ among treatments. Chlorophyll concentration of plants grown under $564 \mu \mathrm{mol} \cdot \mathrm{m}^{-2} \cdot \mathrm{s}^{-1}$ had increased $61 \%$, while starch in the stem had decreased $43 \%$ relative to the concentration found at the end of the production period. In C. elegans grown under $306 \mu \mathrm{mol} \cdot \mathrm{m}^{-2} \cdot \mathrm{s}^{-1}$, stem starch depletion was only $13 \%$ during the interior evaluation period. These results indicated that $C$. elegans grown under the highest irradiance level used reserved carbohydrates in the interior environment while adjusting to low light and producing new leaves. Chamaedorea elegans was best acclimatized at the intermediate irradiance and medium fertilizer concentration.
\end{abstract}

Chamaedorea elegans is one of the most popular potted foliage plants used in interiorscapes due to its ability to withstand low irradiance levels. Cultural practices can be modified to acclimatize potted foliage plants, especially dicots, to interior conditions (Conover and Poole, 1977). Acclimatized foliage plants have a lower light compensation point (LCP), lower dark respiration (Fails et al., 1982c), and higher chlorophyll concentration than nonacclimatized plants (Conover and Poole, 1975), which enables them to survive the low irradiance of interior environments. Only limited research has been conducted on the effect of irradiance level on carbohydrate concentration in foliage plants and the relevance of carbohydrates to the process of acclimatization. In Ficus benjamina $\mathrm{L}$. (Milks et al., 1979), root and leaf carbohydrates decreased during the holding period regardless of the irradiance during production. Fails et al. (1982b) found that, when plants

Received for publication 8 June 1995. Accepted for publication 25 Mar. 1996. Florida Agricultural Experiment Station Journal Series no. R-04462. We gratefully acknowledge the support provided by the Spanish Ministry of Agriculture and Instituto Nacional de Investigaciones Agrarias. The assistance of Ria T. Leonard and Carolyn A. Bartuska is also appreciated. The cost of publishing this paper was defrayed in part by the payment of page charges. Under postal regulations, this paper therefore must be hereby marked advertisement solely to indicate this fact. were moved indoors, root carbohydrates were used in the production of new leaves on sungrown plants at a rate nearly five times higher than in shade-grown or acclimatized plants. However, relationships between carbohydrate concentration at the end of production and its role during the holding period remain inconclusive.

Cultural factors affecting production of $C$. elegans have been studied extensively by Poole and Henley (1981) and Burch (1982). However, the relationship of cultural practices to acclimatization and interior performance of $C$. elegans has not been investigated. In fact, to our knowledge, there is no information available on acclimatization of monocots. Fonteno and McWilliams (1976) were first to report on the LCP of commonly used foliage plants. They found an LCP of $103 \mu \mathrm{mol} \cdot \mathrm{m}^{-2} \cdot \mathrm{s}^{-1}$ for greenhouse-grown, nonacclimatized $C$. elegans; this is a very high value if the plant has to survive an interiorscape (Conover and Poole, 1984). The following research was conducted to study the effect of irradiance level and fertilizer rate during production on acclimatization of $C$. elegans. Our objective was to investigate whether $C$. elegans undergoes physiological and anatomical changes similar to dicots during acclimatization.

\section{Material and Methods}

A $3 \times 3$ factorial experiment with three irradiance levels as a main plot and three fertilizer rates as a subplot, with four replications, was initiated 21 May 1991 with two plants per experimental unit. Chamaedorea elegans seedlings (20 to $25 \mathrm{~cm}$ tall) were planted in 15-cm (1.6-liter) plastic pots containing Vergro Klay Mix (Verlite Co., Tampa, Fla.). Plants were placed on raised benches in a fiberglass, fan and pad-cooled greenhouse in Gainesville, Fla., and grown for 4 months.

Irradiance levels, taken at noon with a model LI-185A quantum sensor (LI-COR, Lincoln, Neb.) included 162, 306, and 564 $\mu \mathrm{mol} \cdot \mathrm{m}^{-2} \cdot \mathrm{s}^{-1}$. The two lower values were achieved by placing black polypropylene shadecloth on metal structures above the benches. The natural irradiance inside the greenhouse provided the highest level. Fertilizer was applied once per week at 220,440 , or $880 \mathrm{mg} /$ pot from a $20 \mathrm{~N}-4.7 \mathrm{P}-16.6 \mathrm{~K}$ soluble fertilizer. Plants were watered as needed at other times.

At the end of the production phase on 2 Oct., one plant per experimental unit was used for analysis and the other was moved to an interior room and remained there for 2 months. Plants were maintained at $20 \mu \mathrm{mol} \cdot \mathrm{m}^{-2} \cdot \mathrm{s}^{-1}$ of irradiance from cool-white fluorescent lamps for $12 \mathrm{~h}$ daily at $25 \pm 1 \mathrm{C}$ with $50 \% \pm 5 \%$ relative humidity.

Light compensation point; dry weight(DW) of leaflets, stems, and roots; number of fronds; nonstructural carbohydrates (soluble sugars and starch concentration of roots, stems, and leaves); and chlorophyll concentration were determined at the end of production and interior holding periods. The LCP was determined with an infrared gas analyzer (model AR600R; Anarad, Santa Barbara, Calif.) using a closed gas exchange system. In addition, at the end of production, mature fronds were examined microscopically.

Total soluble sugar and starch concentrations were determined using the phenolsulfuric method (Dubois et al., 1956) and expressed as glucose $\left(\mathrm{mg}^{\circ} \mathrm{g}^{-1}\right)$, dry-weight basis. Starch was previously digested with $\alpha$ amylase and amyloglucosidase. Chlorophyll $\left(\mathrm{Chl} ; \mathrm{g} \cdot \mathrm{cm}^{-2}\right)$ was measured on a recently mature frond following procedures established by Bruisma (1963). Samples for microscopic examination were taken from recently matured leaves; fixed in formalin, acetic acid, and alcohol (FAA); dehydrated in tertiary butyl alcohol; embedded in paraffin; sectioned at 10 $\mu \mathrm{m}$; and stained with toluidine blue. Sections were analyzed with a Wild Heerbrugg (model 368025; Datco, Clearwater, Fla.) light microscope. Data were subjected to analysis of variance and orthogonal comparisons were used to examine differences among means.

\section{Results and Discussion}

At the end of production, LCP ranged from $20 \mu \mathrm{mol} \cdot \mathrm{m}^{-2} \cdot \mathrm{s}^{-1}$ at the low production irradiance to $40 \mu \mathrm{mol} \cdot \mathrm{m}^{-2} \cdot \mathrm{s}^{-1}$ at the highest one. During the interior holding period, LCP of plants grown under the intermediate and highest irradiance levels declined, while LCP of plants grown under the lowest irradiance did not change (Table 1). Thus, there was no difference in LCP between plants grown at initially different irradiance levels after 8 weeks 
indoors. Reduction of LCP in plants grown or acclimatized at low irradiances have been reported for other foliage plants (Fails et al., 1982c; Fonteno and McWilliams, 1978; Pass and Hartley, 1979).

Increasing fertilizer had lowered the LCP of C. elegans at the three irradiances tested at the end of the production phase (Table 1). Data in the literature in relation to the effect of fertilizer rates on LCP are contradictory. LCP of Ficus benjamina increased as fertilizer rates increased (Collard et al., 1977). Increased N levels increased LCP of sun-grown $F$. benjamina, while higher $\mathrm{N}$ levels under $47 \%$ light exclusion reduced LCP (Johnson et al., 1979). Joiner et al. (1980) found that increased $\mathrm{N}$ and $\mathrm{K}$ in $47 \%$ light exclusion reduced LCP in $F$. benjamina. Based on these results and previous research, production irradiance has more influence on LCP than fertilizer.

Leaf Chl concentration increased linearly as production irradiance decreased but was not affected by fertilizer level during production (Table 1). At the end of the interior holding period, total $\mathrm{Chl}$ had increased in plants grown under the highest irradiance but remained at production levels under the other two irradiances (Table 1). These results agree with previous work on Dracaena marginata Lam. (Conover and Poole, 1975), Peperomia obtusifolia (L.) A. Dietr. (Mbah et al., 1983), and $F$. benjamina (Guy and Haskell, 1987). Fertilizer rate increased $\mathrm{Chl}$ levels in $F$. benjamina (Milks et al., 1979); however, it did not affect leaf $\mathrm{Chl}$ in our study. The decrease in LCP of plants grown under 306 and 564 $\mu \mathrm{mol} \cdot \mathrm{m}^{-2} \cdot \mathrm{s}^{-1}$ and increase in Chl concentration in plants grown under $564 \mu \mathrm{mol} \cdot \mathrm{m}^{-2} \cdot \mathrm{s}^{-1}$ during interior holding demonstrates the high potential of C. elegans to acclimatize to low light environments.

By the marketable stage, production irradiance had not affected the total number of fronds produced, but increasing the fertilizer rate reduced the number of fronds (Table 1). The same trend was observed after the interior holding period; the number of fronds increased in all treatments during the interior evaluation period (Table 1). A higher partitioning toward the shoot resulted in a higher shoot: root ratio as fertilizer and shade increased (data not shown).

At the end of the production period, plants grown at the intermediate irradiance had a higher leaf soluble sugars concentration than those under the other two irradiances (Table 2). Increasing fertilizer lowered soluble sugars in the stem, while the response was quadratic in leaves and roots. After the interior holding period, soluble sugars concentrations were similar to those at the end of production for all treatments (Table 2).

Irradiance level and fertilizer rate interacted to influence leaf, stem, and root starch concentration during production, and root starch after 2 months indoors (Table 3 ). Plants grown under $564 \mu \mathrm{mol} \cdot \mathrm{m}^{-2} \cdot \mathrm{s}^{-1}$ and fertilized weekly with $\mathrm{N}$ at 220 or $440 \mathrm{mg} /$ pot had the highest level of stem and root starch. However, during 2 months in an interior environment, stem starch concentration of plants grown

Table 1. Light compensation point (LCP; $\left.\mu \mathrm{mol} \cdot \mathrm{m}^{-2} \cdot \mathrm{s}^{-1}\right)$, chlorophyll concentration $\left(\mathrm{Chl} ; \mathrm{mg} \cdot \mathrm{cm}^{-2}\right)$, and number of fronds of Chamaedorea elegans at the marketable stage and after 2 months indoors.

\begin{tabular}{|c|c|c|c|c|c|c|}
\hline \multirow[b]{2}{*}{ Variable } & \multicolumn{3}{|c|}{ Production } & \multicolumn{3}{|c|}{ After 2 months indoors } \\
\hline & $\overline{\mathrm{LCP}}$ & Chl & $\overline{\text { Fronds }}$ & $\overline{\mathrm{LCP}}$ & $\mathrm{Chl}$ & $\overline{\text { Fronds }}$ \\
\hline \multicolumn{7}{|c|}{ Irradiance $\left(\mu \mathrm{mol} \cdot \mathrm{m}^{-2} \cdot \mathrm{s}^{-1}\right)$} \\
\hline 162 & 20 & 0.057 & 23.3 & 20 & 0.054 & 25.7 \\
\hline 306 & 32 & 0.052 & 24.9 & 20 & 0.054 & 26.8 \\
\hline 564 & 40 & 0.042 & 26.1 & 21 & 0.068 & 27.8 \\
\hline \multicolumn{7}{|l|}{ Significance } \\
\hline Linear & $* *$ & ** & NS & NS & $*$ & NS \\
\hline Quadratic & NS & NS & NS & NS & NS & NS \\
\hline \multicolumn{7}{|c|}{ Fertilizer (mg/pot weekly) } \\
\hline 220 & 36 & 0.044 & 27.5 & 24 & 0.059 & 29.4 \\
\hline 440 & 29 & 0.052 & 24.9 & 19 & 0.061 & 26.7 \\
\hline 880 & 27 & 0.054 & 21.9 & 18 & 0.056 & 24.2 \\
\hline \multicolumn{7}{|l|}{ Significance } \\
\hline Linear & $*$ & NS & ** & $* *$ & NS & ** \\
\hline Quadratic & NS & NS & $* *$ & NS & NS & $* *$ \\
\hline Interaction & NS & NS & NS & NS & NS & NS \\
\hline
\end{tabular}

${ }_{\text {ss, }, * * *}$ Nonsignificant or significant at $P \leq 0.05$ or 0.01 , respectively, $\mathrm{n}=4$.

Table 2. Effect of irradiance and fertilizer rate on total soluble sugars concentration, expressed as glucose (mg. $\mathrm{g}^{-1}$, dry-weight basis), of Chamaedorea elegans at the end of production and after 2 months indoors.

\begin{tabular}{|c|c|c|c|c|c|c|}
\hline \multirow[b]{3}{*}{ Variable } & \multicolumn{6}{|c|}{ Soluble sugars $\left(\mathrm{mg} \cdot \mathrm{g}^{-1}\right)$} \\
\hline & \multicolumn{3}{|c|}{ Production } & \multicolumn{3}{|c|}{ After 2 months indoors } \\
\hline & Leaf & Stem & Root & Leaf & Stem & Root \\
\hline \multicolumn{7}{|c|}{ Irradiance $\left(\mu \mathrm{mol} \cdot \mathrm{m}^{-2} \cdot \mathrm{s}^{-1}\right)$} \\
\hline 162 & 48.3 & 47.9 & 30.5 & 48.2 & 48.5 & 35.2 \\
\hline 306 & 54.2 & 51.0 & 33.6 & 48.2 & 47.4 & 33.9 \\
\hline 564 & 47.6 & 53.2 & 31.3 & 47.7 & 48.4 & 33.4 \\
\hline \multicolumn{7}{|l|}{ Significance } \\
\hline Linear & NS & NS & NS & NS & NS & NS \\
\hline Quadratic & $* *$ & NS & NS & NS & NS & NS \\
\hline \multicolumn{7}{|c|}{ Fertilizer (mg/pot weekly) } \\
\hline 220 & 53.1 & 53.9 & 32.8 & 47.7 & 51.4 & 36.9 \\
\hline 440 & 51.4 & 51.5 & 30.3 & 48.7 & 46.3 & 32.7 \\
\hline 880 & 45.7 & 46.7 & 32.7 & 47.9 & 46.5 & 32.8 \\
\hline \multicolumn{7}{|l|}{ Significance } \\
\hline Linear & ** & ** & NS & NS & ** & ** \\
\hline Quadratic & $* *$ & NS & $*$ & NS & $* *$ & ** \\
\hline Interaction & NS & NS & NS & NS & NS & NS \\
\hline
\end{tabular}

Ns, ${ }^{*},{ }^{* *}$ Nonsignificant or significant at $P \leq 0.05$ or 0.01 , respectively, $\mathrm{n}=4$.

under the highest irradiance level decreased $43 \%$, while depletion of stem starch was only $13 \%$ and $8 \%$ in plants grown under the intermediate and lowest irradiance level, respectively. In addition, root starch decreased $29 \%$ during the interior holding period in plants grown under the highest irradiance level, but only $2 \%$ in plants grown under 306 $\mu \mathrm{mol} \cdot \mathrm{m}^{-2} \cdot \mathrm{s}^{-1}$. Root starch concentration had increased $17 \%$ during 2 months indoors in plants grown under $162 \mu \mathrm{mol} \cdot \mathrm{m}^{-2} \cdot \mathrm{s}^{-1}$. In $F$. benjamina placed indoors for 3 months, leaf and root carbohydrate concentration decreased for all treatments (Milks et al., 1979). Our results suggest that stem and root starch concentrations of plants grown under $564 \mu \mathrm{mol} \cdot \mathrm{m}^{-}$ ${ }^{2} \cdot \mathrm{s}^{-1}$ were used by the plant during the interior holding period in maintenance and to produce new fronds while the plant is adjusting to the new low-irradiance environment by lowering its LCP and increasing Chl concentration. However, plants grown under the intermediate and lowest irradiance levels, having lower LCP, presumably had a greater photosynthetic efficiency in the low-irradiance environment. Thus, they were able to produce new fronds without depleting carbohydrate reserves. Fails et al. (1982b) found that root carbohydrate reserves were used to produce new leaves on sun-grown $F$. benjamina at a rate nearly five times greater than in shade-grown or acclimatized plants.

Microscopic observations showed one or two layers of elongated palisade mesophyll cells in leaves grown under the highest irradiance (Fig. 1, top). Elongation of palisade cells and an overall increase in cell size resulted in slightly thicker leaves. The mesophyll of leaves grown under the lowest irradiance level was not differentiated into distinct palisade and spongy mesophyll cells (Fig. 1, bottom). Chloroplasts in leaves grown at the lowest irradiance level were clearly differentiated, dispersed throughout the palisade cells, and were larger and stained more heavily than in highirradiance-grown leaves. Similar results were found by Fails et al. (1982a) in sun- and shadegrown F . benjamina. Zurzycki (1953), as reported by McConnell et al. (1984), proposed that at optimum irradiance level, palisade cell chloroplasts would be dispersed throughout the cell, while at maximum irradiance level they would be concentrated in layers. Grana stacks are more highly developed in low light, and chloroplast orientation tends to maximize exposure of total chloroplast area, further enhancing light interception (Haupt, 1973). In $C$. elegans leaves, almost all abaxial mesophyll cells were tightly appressed to each other, regardless of the irradiance level. This obser- 
Table 3. Interaction effect of fertilizer rate and irradiance level on leaf, stem, and root starch concentrations, expressed as glucose (mg. $\mathrm{g}^{-1}$, dry-weight basis), of Chamaedorea elegans at the end of production and on root starch after 2 months indoors. Effect of fertilizer rate and irradiance level as main factors on leaf and stem starch concentrations after 2 months indoors.

\begin{tabular}{|c|c|c|c|c|c|c|c|c|c|c|c|c|c|c|}
\hline \multirow[b]{5}{*}{ Variable } & \multicolumn{14}{|c|}{ Starch $\left(\mathrm{mg} \cdot \mathrm{g}^{-1}\right)$} \\
\hline & \multicolumn{9}{|c|}{ Production } & \multicolumn{5}{|c|}{ After 2 months indoors } \\
\hline & \multicolumn{3}{|c|}{ Leaf } & \multicolumn{3}{|c|}{ Stem } & \multicolumn{3}{|c|}{ Root } & \multirow[b]{3}{*}{ Leaf } & \multirow[b]{3}{*}{ Stem } & \multirow{2}{*}{\multicolumn{3}{|c|}{$\frac{\text { Root }}{\text { Irradiance }\left(\mu \mathrm{mol} \cdot \mathrm{m}^{-2} \cdot \mathrm{s}^{-1}\right)}$}} \\
\hline & Irrad & $(\mu \mathrm{m}$ & $\left.-2 \cdot \mathrm{s}^{-1}\right)$ & Irrad & $\mathrm{e}(\mu \mathrm{m}$ & $\left.-2 \cdot \mathrm{s}^{-1}\right)$ & Irradic & $\mathrm{ee}(\mu \mathrm{m}$ & $\overline{\left.n^{-2} \cdot s^{-1}\right)}$ & & & & & \\
\hline & $\overline{162}$ & 306 & 564 & 162 & 306 & 564 & 162 & 306 & 564 & & & 162 & 306 & 564 \\
\hline \multicolumn{15}{|c|}{ Fertilizer (mg/pot weekly) } \\
\hline 220 & 24 & 18 & 19 & 93 & 105 & 158 & 98 & 110 & 146 & 9.2 & 94 & 111 & 90 & 96 \\
\hline 440 & 19 & 23 & 19 & 122 & 124 & 156 & 95 & 117 & 133 & 7.9 & 120 & 134 & 123 & 78 \\
\hline 880 & 18 & 18 & 17 & 73 & 145 & 114 & 79 & 111 & 96 & 7.2 & 62 & 73 & 118 & 92 \\
\hline \multicolumn{15}{|l|}{ Significance } \\
\hline Linear & * & NS & NS & NS & $* *$ & ** & NS & NS & $* *$ & $* *$ & ** & $* *$ & NS & NS \\
\hline Quadratic & NS & $* *$ & NS & $*$ & NS & NS & NS & NS & NS & NS & $* *$ & $* *$ & NS & NS \\
\hline Irradiance & & & & & & & & & & NS & NS & & & \\
\hline Interaction & & $* *$ & & & $* *$ & & & ** & & NS & NS & & *** & \\
\hline
\end{tabular}

Ns, *,** Nonsignificant or significant at $P \leq 0.05$ or 0.01 , respectively, $\mathrm{n}=4$.
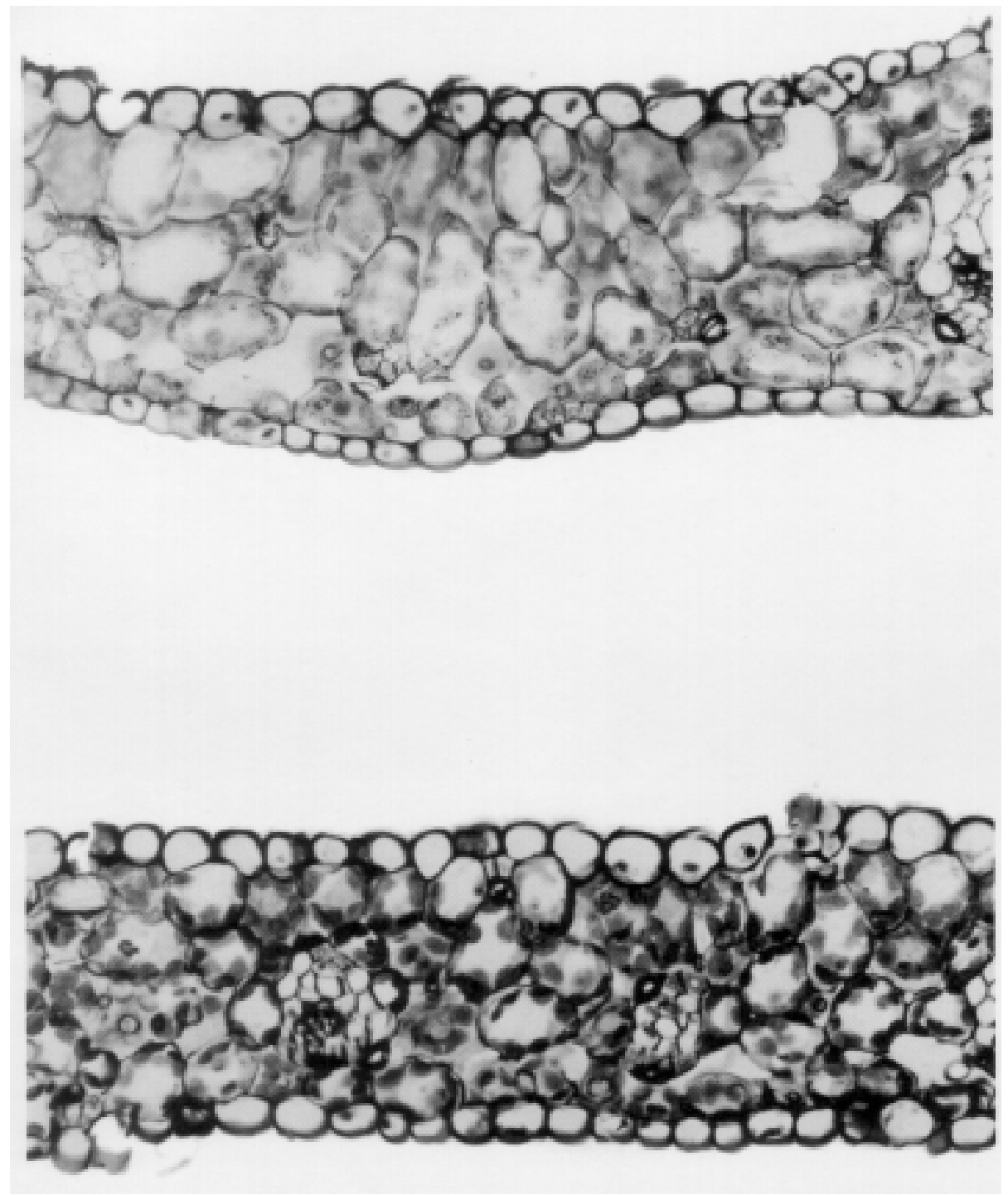

Fig. 1. Light microscope micrographs $(\times 400)$ showing leaf cross sections of Chamaedorea elegans grown at (top) 564 and (bottom) $162 \mu \mathrm{mol} \cdot \mathrm{m}^{-2} \cdot \mathrm{s}^{-1}$.

vation is similar to that reported by Broschat et al. (1989) in another palm, Ptychosperma elegans (R.Br.) Blume.

We believe our results to be the first demonstrating that a monocot, $C$. elegans, adapts to production irradiance level and acclima- tizes through changes in leaf anatomy, LCP, and $\mathrm{Chl}$ concentration as occurs in dicots. Reduction in LCP when plants were moved to the interior environment reflects the high acclimatization potential of $C$. elegans. The higher carbohydrate reserves of plants grown under the highest irradiance provides energy while the plant is adapting physiologically to a low-irradiance environment. Chamaedorea elegans were acclimatized best at the intermediate irradiance level and medium fertilizer rate. These treatments produced plants with a relatively low LCP and a higher carbohydrate concentration than those at the lowest irradiance tested.

\section{Literature Cited}

Broschat, T.K., H. Donselman, and D.B. McConnell. 1989. Light acclimation of Ptychosperma elegans. HortScience 24:267-268.

Bruisnma, J. 1963. The quantitative analysis of chlorophylls a and b in plant extracts. Photochem. and Photobiol. (Chlor. Metabol. Sym.) 2:241249.

Burch, E.J. 1982. Summary chart for two foliage crops. Foliage Digest 5(1):8.

Collard, R.C., J.N. Joiner, C.A. Conover, and D.B. McConnell. 1977. Influence of shade and fertilizer on LCP of Ficus benjamina L. J. Amer. Soc. Hort. Sci. 102:447-449.

Conover, C.A. and R.T. Poole. 1975. Influence of shade and fertilizer on production and acclimatization of Dracaena marginata. Proc. Fla. State Hort. Soc. p. 606-608.

Conover, C.A. and R.T. Poole. 1977. Effects of cultural practices on acclimatization of Ficus benjamina L. J. Amer. Soc. Hort. Sci. 102:529531.

Conover, C.A. and R.T. Poole. 1984. Acclimatization of indoor foliage plants. Hort. Rev. 6:119154.

Dubois, M., K.A. Giles, J.K. Hamilton, P.A. Rebers, and F. Smith. 1956. Colorimetric method for determination of sugars and related substances. Anal. Chem. 28:350-356.

Fails, B.S., A.J. Lewis, and J.A. Barden. 1982a. Anatomy and morphology of sun- and shadegrown Ficus benjamina. J. Amer. Soc. Hort. Sci. 107:754-757.

Fails, B.S., A.J. Lewis, and J.A. Barden. 1982b. Net photosynthesis and transpiration of sun and shade-grown Ficus benjamina leaves. J. Amer. Soc. Hort. Sci. 107:758-761.

Fails, B.S., A.J. Lewis, and J.A. Barden. 1982c. Light acclimatization potential of Ficus benjamina. J. Amer. Soc. Hort. Sci. 107:762766.

Fonteno, W.C. and E.L. McWilliams. 1976. CO uptake rates of selected foliage plants. HortScience 11:230. (Abstr.)

Fonteno, W.C. and E.L. McWilliams. 1978. Light compensation point and acclimatization of four 
tropical foliage plants. J. Amer. Soc. Hort. Sci. 103:52-56.

Guy, C.L. and D. Haskell. 1987. Changes in leaf pigment and protein content during light acclimatization of Ficus benjamina. HortScience 22:1081.

Haupt, W. 1973. Role of light in chloroplast movement. BioScience 23:289-296.

Johnson, C.R., J.K. Krantz, J.N. Joiner, and C.A. Conover. 1979. Light compensation point and leaf distribution of Ficus benjamina as affected by light intensity and nitrogen-potassium nutrition. J. Amer. Soc. Hort. Sci. 104:335-338.
Joiner, J.N., C.R. Johnson, and J.K. Krantz. 1980. Effect of light and nitrogen and potassium levels on growth and light compensation point of Ficus benjamina L. J. Amer. Soc. Hort. Sci. 105:170173.

Mbah, B.N., E.L. McWilliams, and K.J. McCree. 1983. Carbon balance of Peperomia obtusifolia plants during acclimatization to low PPFD. J. Amer. Soc. Hort. Sci. 108:769-773.

McConnell, D.B., P. Rugaber, T.J. Sheehan, and R.J.Henny. 1984. Light levels alter leaf anatomy of Aphelandra squarrosa 'Dania'. J. Amer. Soc. Hort. Sci. 109:298-301.

Milks, R.R., J.N. Joiner,L.A. Garard, C.A. Conover, and B. Tjia. 1979. Influence of acclimatization on carbohydrate production and translocation of Ficus benjamina. J. Amer. Soc. Hort. Sci. 104:410-413.

Pass, R.G. and D.E. Hartley. 1979. Net photosynthesis of three foliage plants under low irradiation levels. J. Amer. Soc. Hort. Sci. 104:745748.

Poole, R.T. and R.W. Henley. 1981. Constant fertilization of foliage plants. J. Amer. Soc. Hort. Sci. 106:61-63.

Zurzycki, J. 1953. Arrangement of chloroplasts and light absorption in plant cells. Acta Soc. Bot. Poloniae 22:299-320. 